University of New Haven

University of

New Haven

Digital Commons@ New Haven

Civil Engineering Faculty Publications

Civil Engineering

7-11-2017

\title{
Performance Study on Evacuated Tubular Collector Coupled Solar Still in West Texas Climate
}

Roy Issa

West Texas A \& M University

Byungik Chang

University of New Haven, BChang@newhaven.edu

Follow this and additional works at: https://digitalcommons.newhaven.edu/civilengineeringfacpubs

Part of the Civil Engineering Commons, and the Environmental Engineering Commons

\section{Publisher Citation}

Issa, R. J., \& Chang, B. (2017). Performance study on evacuated tubular collector coupled solar still in West Texas climate. International Journal of Green Energy, 14(10), 793-800.

\section{Comments}

This is an Accepted Manuscript of an article published by Taylor \& Francis in International Journal of Green Energy on July 11, 2017, available online: https://doi.org/10.1080/15435075.2017.1328422 


\title{
PERFORMANCE STUDY ON A SOLAR STILL AUGMENTED WITH EVACUATED SOLAR TUBES
}

\author{
Roy J. Issa ${ }^{a^{*}}$ and Byungik Chang ${ }^{b}$
}

${ }^{a}$ Associate Professor, School of Engineering and Computer Science, West Texas A\&M University, Canyon, Texas 79016, USA

${ }^{\mathrm{b}}$ Associate Professor, Department of Civil and Environmental Engineering, University of New Haven, West Haven, Connecticut 065616, USA

* Corresponding author

Roy Issa, Ph.D., P.E.

Associate Professor of Mechanical Engineering

School of Engineering and Computer Science

West Texas A\&M University

WTAMU Box 60767

Canyon, Texas 79016, USA

Tel: 1-806-651-5261

Email: riisa@wtamu.edu

\begin{abstract}
Experimental studies were conducted on a single basin active solar distillation system augmented with a solar collector using evacuated solar tubes. Tests were conducted over several days under the climatic conditions of West Texas to evaluate the effect evacuated solar tubes have on the daily distillate yield rate. To investigate the feasibility of the solar tubes, passive and active solar stills were studied. Solar stills with and without exterior insulation were also examined. The maximum daily production was 1.4 $\mathrm{L} / \mathrm{m}^{2} /$ day for the passive distillation system, and $3.6 \mathrm{~L} / \mathrm{m}^{2} /$ day for the active distillation system using evacuated solar tubes. The tests showed the augmentation of the still with evacuated solar tubes increased its production rate by 263\%. Also, for the same average water temperature in the basin, an insulated basin produced a higher amount of distillate compared to an un-insulated basin. The peak in the thermal efficiency of the active and passive systems was about 19\%.
\end{abstract}

Keywords: Passive, Active, Solar Distillation, Yield Rate 


\section{Introduction}

West Texas has a semi-arid environment with an average annual rainfall of about 18.8 inches based on the latest meteorological data since 2003 [1]. The monthly average temperature in west Texas ranges from $2.8{ }^{\circ} \mathrm{C}$ in January to $25.7^{\circ} \mathrm{C}$ in July with mean monthly sunshine hours of 3,300. The average annual wind speed in the area is $22 \mathrm{~km} / \mathrm{hr}$, and the average relative humidity is $44 \%$. The Ogallala Aquifer, one of the largest underground fresh water aquifers in the world, is the primary source of agriculture irrigation in this area. Due to heavier use and a lack of adequate recharge to replenish the aquifer's supply, it became apparent several decades ago that the aquifer was declining significantly. Some studies have shown that the Ogallala aquifer is expected to become non-productive by the year 2030 [2]. As a result, several water management practices that include water conservation, reuse and reclamation of wastewater were put into effect to extend the life time of the aquifer [3]. The purpose of this study is to evaluate the effectiveness of a solar still augmented with evacuated solar tubes collector in the distillation of wastewater produced in agricultural processing facilities in west Texas.

In passive solar distillation systems, the basin of the solar still is filled with wastewater, and solar radiation passing through the glass cover heats up the water. There is no additional source of energy to heat up the water. The evaporating water condenses on the inner side of the glass, slides along the cover into a trough and drains into a holding container. Several solar distillation studies have been conducted by researchers in the past. Onyegegbu [4] has conducted a study on solar distillation of muddy pond water in Nsukka, Nigeria. His daily distillation rate ranged from about 0.8 to $1.2 \mathrm{~L} / \mathrm{m}^{2} /$ day, and the water temperature ranged from 20 to $40{ }^{\circ} \mathrm{C}$. On a daily basis, his muddy and clear water tests produced the same distillate output. Onyegegbu [5] also studied the nocturnal performance of solar stills. His study showed nocturnal distillation accounted for about 50 to $78 \%$ of the total daily output. The results showed the distillate output to be distinctively determined by the stored thermal energy in the still at sunset. Potoglou et al. [6] performed a study on solar distillation of olive mill wastewater in Athens, Greece. The depth of wastewater in the basin ranged from 1 to $4 \mathrm{~cm}$. Their results showed slight variation in the distillation rate with the change in depth. The daily average distillate ranged from 0.9 to $1.7 \mathrm{~L} / \mathrm{m}^{2} /$ day, and liquid temperature in the basin ranged from 16.5 to $59^{\circ} \mathrm{C}$. Okeke et al. [7] studied the effects of coal and charcoal on solar still performance in Nsukka, Nigeria. The addition of charcoal was seen to increase the day-time yield because charcoal absorbs energy more efficiently than water. Their production rate ranged from 0.95 to $1.46 \mathrm{~L} / \mathrm{m}^{2} /$ day.

Ayav and Atagunduz [8] investigated theoretically and experimentally single-basin solar distillation in Izmir, Turkey. The amount of distilled water from a standard single-basin solar still was experimentally measured to be $1.4 \mathrm{~L} / \mathrm{m}^{2} /$ day with the water temperature in the still peaking at around $75^{\circ} \mathrm{C}$, and about $3.0 \mathrm{~L} / \mathrm{m}^{2} /$ day when the still was augmented with a reflector. ElSherbiny and Fath [9] conducted a theoretical study for solar distillation under the climatic conditions of Alexandria, Egypt. For a $5 \mathrm{~cm}$ water depth in the still, their theoretical prediction of the daily distillate production ranged from $0.8 \mathrm{~L} / \mathrm{m}^{2} /$ day in the month of January to $5 \mathrm{~L} / \mathrm{m}^{2} /$ day in July. In 
their simulation, the water temperature exceeded $65^{\circ} \mathrm{C}$. Tiwari and Tiwari [10] examined the effect of basin water depth (ranging from 2 to $18 \mathrm{~cm}$ ) on their solar distillation tests in New Delhi, India. Water depth did not have any significant effect on the daily yield rate during winter time. However during summer time, the daily yield rate decreased by $40 \%$ as the water depth increased from 2 to $18 \mathrm{~cm}$. The daily yield rate changed from 0.5 in winter to $1.9 \mathrm{~L} / \mathrm{m}^{2} /$ day in summer. Abdallah et al. [11] examined the effect of different absorbing materials on the production yield rate of solar stills in Amman, Jordan. Four identical single-slope stills were tested. Three of them contained different absorbing materials: black coated, uncoated steel sponges, and black rocks. The forth tank had no absorbing material and was used as a control. The tank containing black rocks performed the best, and the yield rate was $0.66 \mathrm{~L} / \mathrm{m}^{2} /$ day. The tanks with the coated and uncoated sponges had a yield rate of $0.45 \mathrm{~L} / \mathrm{m}^{2} /$ day, and the control tank had a yield rate of 0.4 $\mathrm{L} / \mathrm{m}^{2} /$ day.

Badran et al. [12] conducted studies on a solar still augmented with a fin-tube flat plate collector. Tests were performed on tap water and saline water. The tests showed the fin-tubes augmentation increased the production rate of the still by $231 \%$ in the case of tap water, and by $52 \%$ in the case of salt water. The still production rate ranged from 2 to $4.6 \mathrm{~L} / \mathrm{m}^{2} /$ day. In another study using flat plate collector made of parallel steel tubes and coupled to a solar still, Badran and Al-Tahaineh [13] discovered the average daily production rate varied from 2.9 to $3.3 \mathrm{~L} / \mathrm{m}^{2} /$ day based on the month of the year. Their tests showed that coupling a solar collector with a still increased the productivity by 36\%. Sampathkumar and Senthilkumar [14] used an evacuated solar tubes collector coupled to a solar still. Their tests revealed that the yield rate of the system was doubled when compared to that of a simple solar still. An analytical study on a solar still integrated with evacuated solar tubes collector was conducted by Singh et al. [15]. The overall energy and exergy efficiencies from their model were found to range from 5.1 to $54.4 \%$ and 0.15 to $8.25 \%$, respectively. The water depth in the still was $3 \mathrm{~cm}$. Based on the simulation, the maximum production rate was $3.8 \mathrm{~kg} / \mathrm{m}^{2} /$ day.

Ahmed et. al. [16] proposed a new multistage evacuated solar distillation system, which developed to improve the efficiency of the solar still and increase the productivity. The influence of the characteristic height variation on the still's estimated productivity was found to be very strong. As the height increases the productivity decreases significantly. An experimental study [17] was conducted in a single slope basin solar still after introducing a floating perforated and folded aluminum sheet over the water surface. This improved the distillate yield considerably when the water depth was high.

From the review of literature on single-basin solar distillation, experimental studies have shown the daily average distillate to range from 0.4 to $1.9 \mathrm{~L} / \mathrm{m}^{2} /$ day for a passive solar still. If the still is coupled to a flat plate collector, the daily yield rate increases to a range from 2.9 to 4.6 $\mathrm{L} / \mathrm{m}^{2} /$ day. The amount of water distillate varied from one study to the other depending on the design of the solar still and conditions such as the incident solar radiation, wind speed and ambient temperature. In general, the theoretical studies had predicted a higher yield rate than the experimental studies. The bulk of the research on active solar stills coupled to flat plate collectors 
have been conducted using conventional metal tubes, and studies conducted using evacuated solar tubes are scarce. The objective of this study is to experimentally investigate the performance of a solar still augmented with evacuated solar tubes collector by examining the effect the evacuated solar tubes have on the daily production yield rate.

\section{Experimental Setup}

A solar still was built at the Alternative Energy Institute on West Texas A\&M University campus for the distillation of waste water produced in agricultural processing facilities. The passive system consisted of a steel basin and a collecting jar to hold the distillate (see Figure 1). The steel basin had a base of dimensions $0.85 \mathrm{~m} \times 0.85 \mathrm{~m}$ and a Plexiglas cover that was inclined at $30^{\circ}$ with respect to the horizontal surface. It was estimated that a surface inclined at this angle would receive about $70 \%$ of the optimum solar radiation intensity throughout the year. Since Canyon has positive latitude, the inclined surface was set to face south. The inclination of the solar still cover causes the condensing distillate to slide down the glass surface and collect into a tray that drains into a holding jar where distilled water is collected. To maximize the amount of heat absorption by the water, the interior walls of the steel basin were painted black. In this passive system, solar radiation received by the water through the Plexiglas cover was the only source of energy for heating the water.

The solar distillation system (Figure 2) was then enhanced by augmenting the solar still with a solar collector; thus converting the system to an active distillation system. Figure 3 describes the schematics diagram of the active distillation system. The solar collector panel was constructed of two arrays of nine evacuated solar tubes paired with parabolic reflectors that were overlaid with Mylar sheeting. The arrays were constructed using plywood, and were hinged together. The nine evacuated solar tubes in each array ran in series, and the two arrays ran in parallel. The evacuated solar tubes, made of borosilicate glass, had double walls with vacuum between the walls to absorb and trap the incoming energy from solar radiation. Figure 4 shows Double-glass wall evacuated solar tube. High reflective aluminum and copper coating was used to minimize the heat loss from the evacuated tubes. The tubes had an inner diameter of $43 \mathrm{~mm}$, an outer diameter of $58 \mathrm{~mm}$, and a length of $500 \mathrm{~mm}$. The purpose of the solar tubes collector was to preheat the water before it entered the basin of the solar. A circulator pump was used for this application. The solar tubes collector provided an extra boost of thermal energy to the circulating water resulting in an increase in the evaporation rate and an improvement in the productivity of the system. 


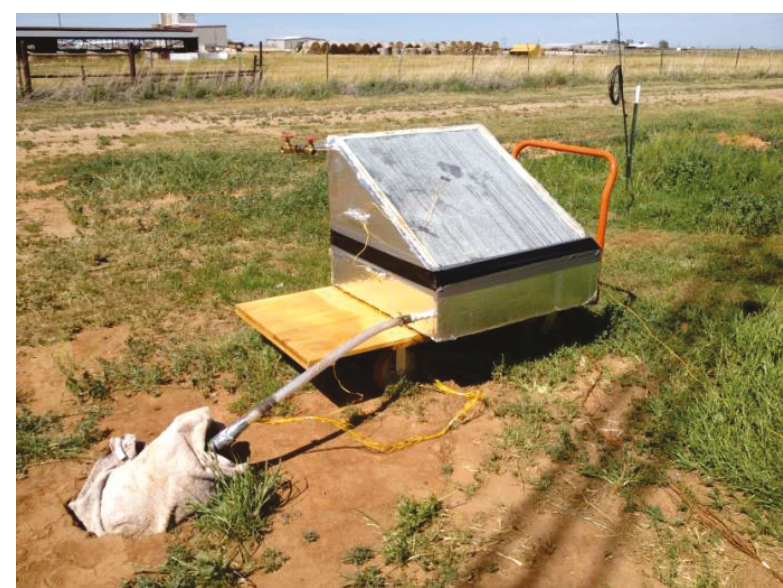

Figure 1. Passive solar distillation system

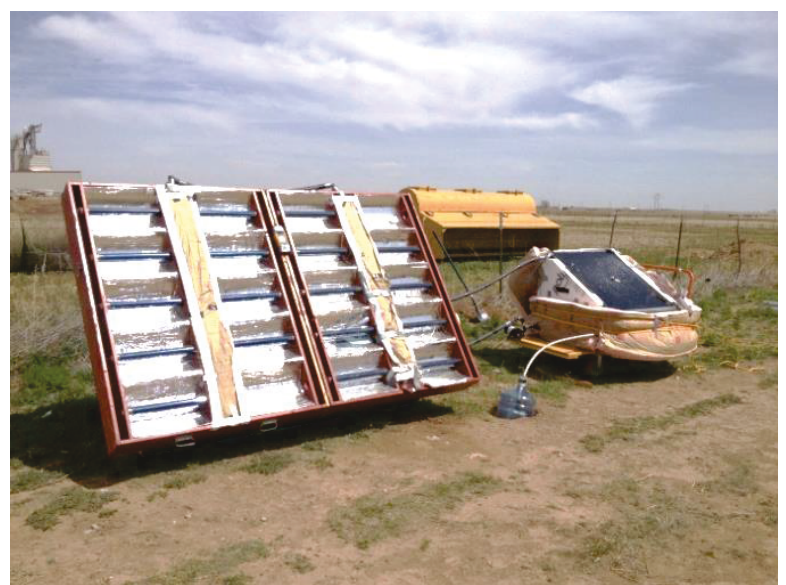

Figure 2. Active solar distillation system

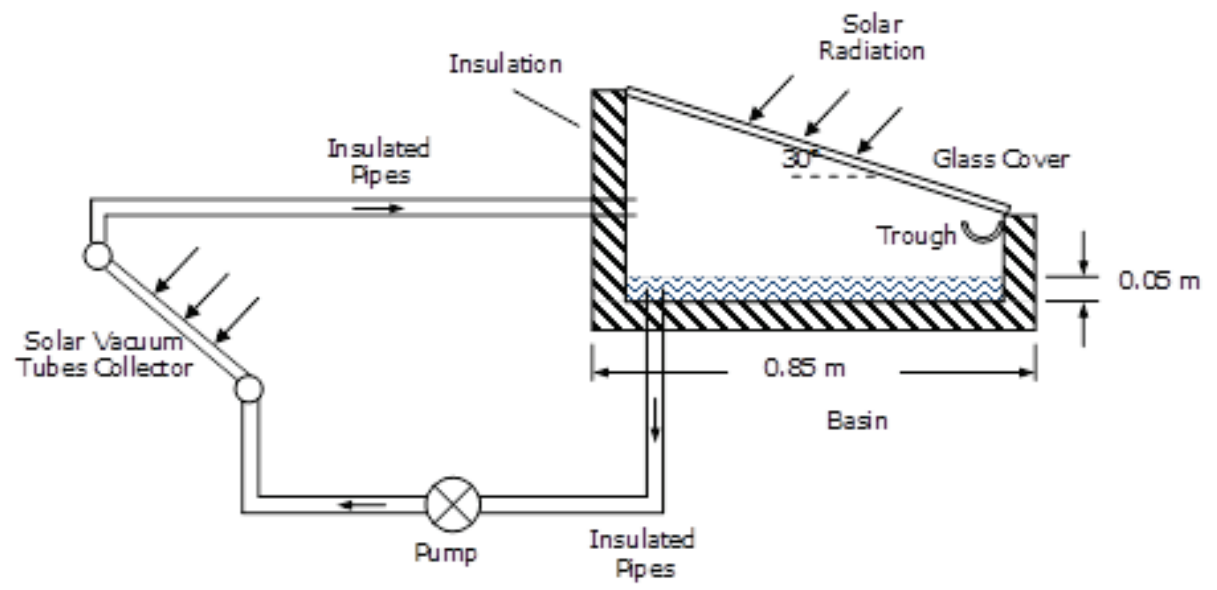

Figure 3. Schematics diagram of the active solar distillation system

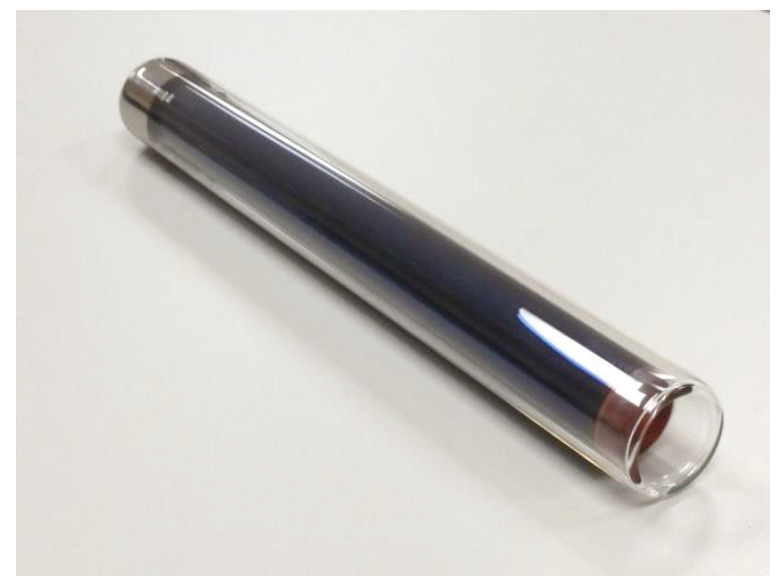

Figure 4. Double-glass wall evacuated solar tube 
Thermocouples were installed inside the still on several walls, on the inner and outer surface of the glass cover, in the water basin, in the still enclosure above the water surface, at the inlet and exit from the solar collector panel, and in the surrounding air outside the still. All thermocouple wires were connected to a data acquisition device (Omega OMB-CHARTSCAN-1400), which in turn was connected to a portable computer that recorded the temperature data at a sampling rate of 1 data point per minute. Daily solar insolation (also referred to as solar radiation intensity) was measured using Solar Survey 200R Irradiance Meter by Seaward Electronic Ltd.

\section{Results and Discussions}

Several tests were conducted to evaluate the performance of the solar still with and without the augmentation under the climatic conditions of west Texas (Tab. 1 in Table 1) for over the past two years. For all tests, temperature data were recorded for a period ranging from three to four days, the duration time of each test. The first series of tests (Tests No. 1 through 7 in Table 1) were conducted on the passive system while the second series of tests (Tests No. 8 through 11 in Table 1) were conducted on the active system. For all tests, water was poured into the still to a depth of $5 \mathrm{~cm}$ for a total volume of 36 liters. The conditions of the tests were as follows. The average wind speed in these tests ranged from 3.61 to $7.29 \mathrm{~m} / \mathrm{s}$, average ambient temperature ranged from 18.4 to $31{ }^{\circ} \mathrm{C}$, and average water temperature in the basin ranged from 25 to $40^{\circ} \mathrm{C}$.

The productivity of the solar still is shown to be a function of the water temperature as shown in Figure 5. For the same water temperature in the basin, the insulated basin (passive system) produced a higher amount of distillate than the un-insulated basin (passive system). On average, the higher the temperature reached by the water in the basin, the higher was the production rate of the still. The results show the augmented still (active system) outperformed the passive distillation system. The maximum production rate reached by the passive system was $1.4 \mathrm{~L} / \mathrm{m}^{2} /$ day, while that reached by the active system was $3.6 \mathrm{~L} / \mathrm{m}^{2} /$ day. 
Table 1. Operating conditions for passive and active stills

\begin{tabular}{|c|c|c|c|c|c|c|c|c|}
\hline \multirow[b]{2}{*}{$\begin{array}{l}\text { Test } \\
\text { No. }\end{array}$} & \multirow[b]{2}{*}{ Dates } & \multirow[b]{2}{*}{ Description } & \multirow[b]{2}{*}{$\begin{array}{l}\text { Duration } \\
\text { (hr) }\end{array}$} & \multicolumn{4}{|c|}{ Average Temperatures } & \multirow[b]{2}{*}{$\begin{array}{l}\text { Distillate } \\
\text { Yield Rate } \\
\text { (L/m²/day) }\end{array}$} \\
\hline & & & & $\begin{array}{l}\mathrm{V}_{\mathrm{w}} \\
(\mathrm{m} / \mathrm{s})\end{array}$ & $\begin{array}{c}\mathrm{T}_{\mathrm{a}} \\
\left({ }^{\circ} \mathrm{C}\right)\end{array}$ & $\begin{array}{l}\mathrm{T}_{\text {encl. }} \\
\left({ }^{\circ} \mathrm{C}\right)\end{array}$ & $\begin{array}{c}\mathrm{T}_{\mathrm{w}} \\
\left({ }^{\circ} \mathrm{C}\right)\end{array}$ & \\
\hline & (Year 1) & & & & & & & \\
\hline 1 & March & $\begin{array}{l}\text { passive, } \\
\text { insulated }\end{array}$ & 81.1 & 5.6 & 25.5 & 39.0 & 31.8 & 1.35 \\
\hline 2 & April & $\begin{array}{l}\text { passive, } \\
\text { insulated }\end{array}$ & 83.0 & 6.4 & 18.4 & 23.8 & 25.4 & 0.11 \\
\hline 3 & April & $\begin{array}{l}\text { passive, } \\
\text { insulated }\end{array}$ & 108.3 & 6.3 & 24.1 & 30.1 & 29.4 & 0.68 \\
\hline 4 & May & $\begin{array}{l}\text { passive, } \\
\text { insulated }\end{array}$ & 90.0 & 5.9 & 27.8 & 34.2 & 31.3 & 0.79 \\
\hline 5 & June & $\begin{array}{l}\text { passive, not } \\
\text { insulated }\end{array}$ & 95.0 & 6.4 & 31.0 & 38.6 & 37.4 & 1.31 \\
\hline 6 & July & $\begin{array}{l}\text { passive, not } \\
\text { insulated }\end{array}$ & 95.8 & 7.3 & 28.3 & 34.9 & 34.1 & 0.76 \\
\hline 7 & August & $\begin{array}{l}\text { passive, not } \\
\text { insulated }\end{array}$ & 96.1 & 3.6 & 25.5 & 31.1 & 30.2 & 0.24 \\
\hline 8 & April & active, insulated & 72 & 6.2 & 20.3 & 27.8 & 29.8 & 2.35 \\
\hline 9 & May & active, insulated & 72 & 6.0 & 16.5 & 26.3 & 27.7 & 3.04 \\
\hline 10 & June & active, insulated & 72 & 6.1 & 29.2 & 38.4 & 39.8 & 3.60 \\
\hline 11 & August & active, insulated & 72 & 5.6 & 26.5 & 36.2 & 38.1 & 2.46 \\
\hline
\end{tabular}

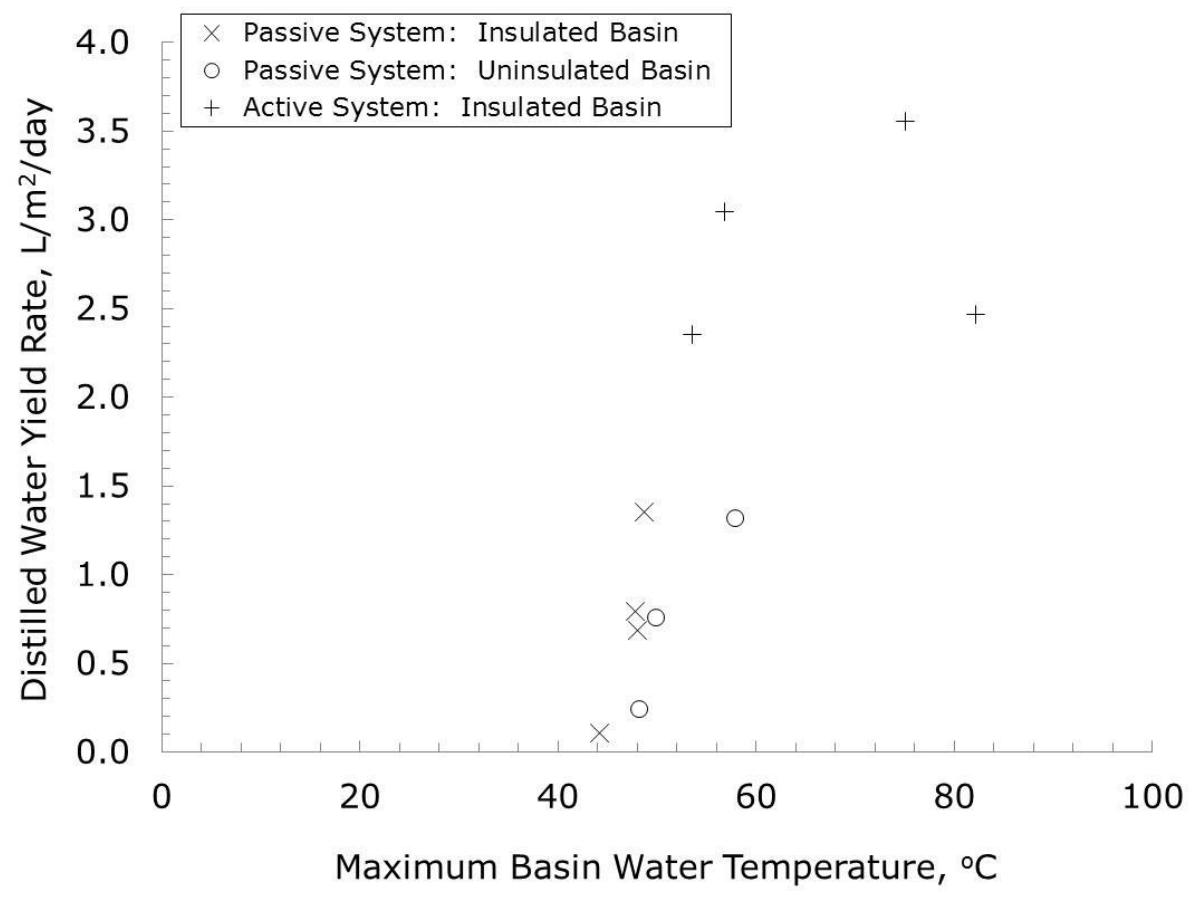

Figure 5. Distilled water yield rate versus maximum water temperature in the basin 
Figure 6 shows typical results of the temperature time history (Test No. 5 in Table 1) of the glass inner and outer surface, basin water, outside ambient air, and humid air inside the enclosure. In this test, temperature data were recorded for a period 95 hours. Water temperature is shown to peak between 55 and $60{ }^{\circ} \mathrm{C}$ during daylight and drop to $22{ }^{\circ} \mathrm{C}$ during the evenings. The ambient temperature peaked at $42{ }^{\circ} \mathrm{C}$ during daylight and dropped to about $21{ }^{\circ} \mathrm{C}$ during the evenings.

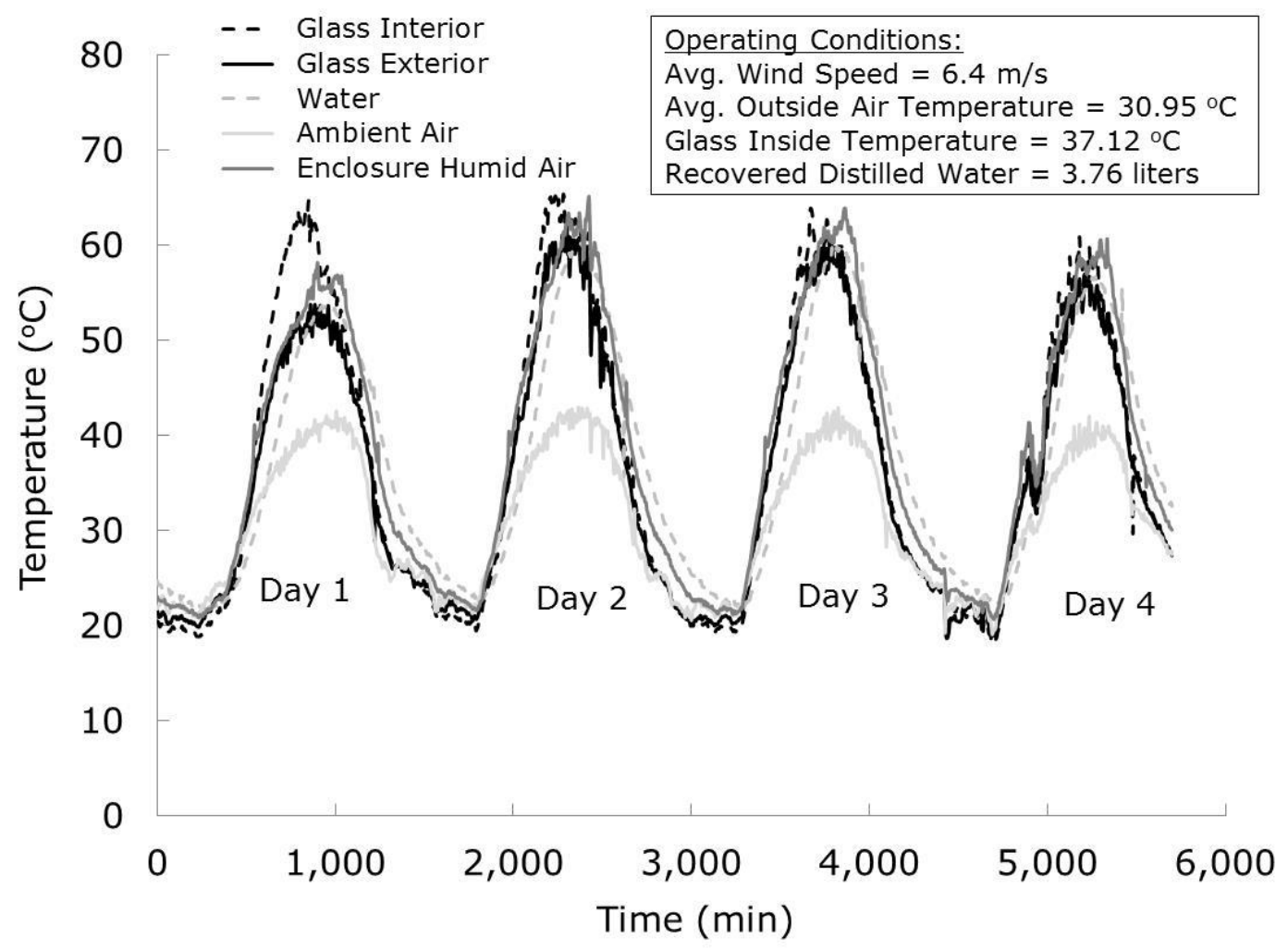

Figure 6. Transient response of the temperature at various locations in the solar distillation system

Figure 7 shows typical results of the time history of the solar insolation (solar radiation intensity) in a 24-hour period. The results are shown for the test conducted on summer season in Canyon, Texas. Solar radiation intensity is shown to reach a peak of $1132 \mathrm{~W} / \mathrm{m}^{2}$ at around 1:30 $\mathrm{pm}$ on that day. The perturbation that is seen in the data is due to presence of clouds moving into the area at certain times during the day. 


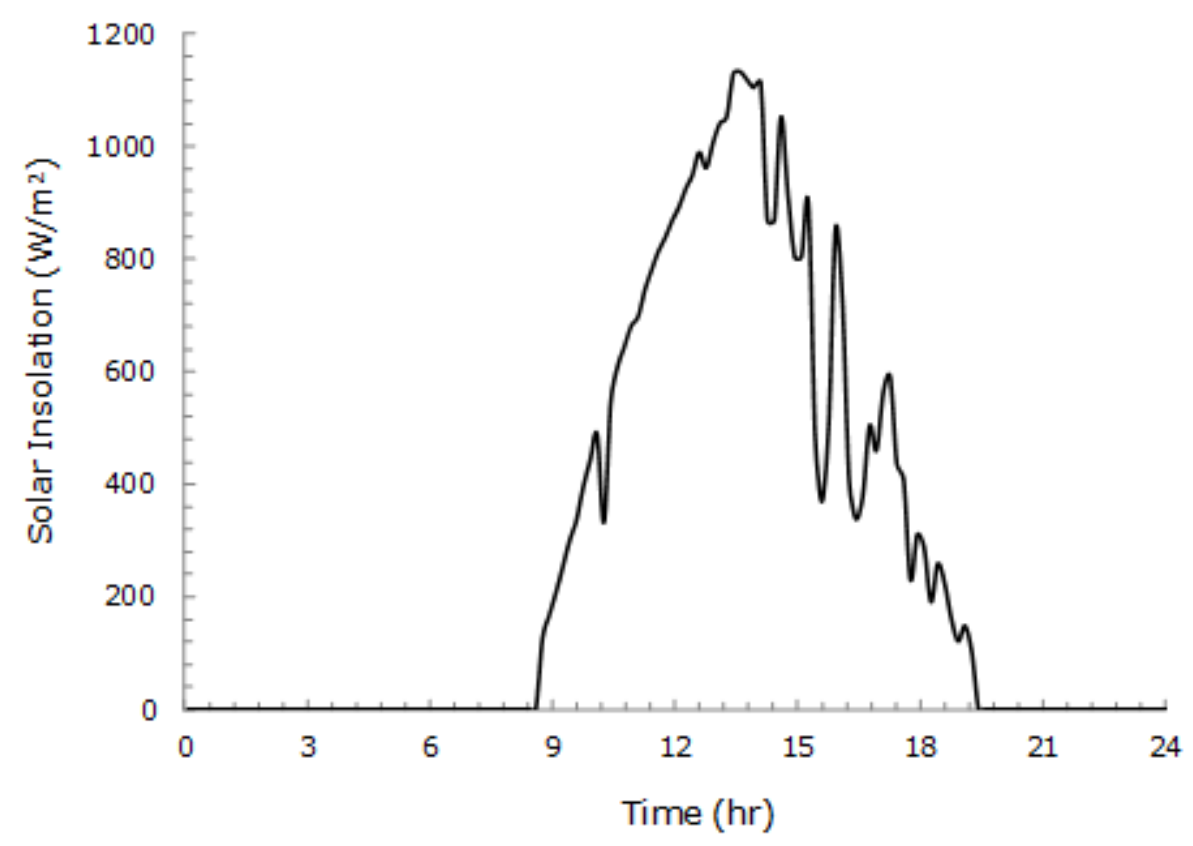

Figure 7. Typical hourly solar insolation (Day 2 of Test No. 5)

The efficiency of the solar still, $\eta$, is defined as the ratio of the amount of energy used for the evaporation of the daily distillate, $Q_{e}$, to the total daily solar insolation, $I_{t}$ :

$$
\eta=\frac{Q_{e}}{I_{t}}
$$

The rate of evaporative heat transfer is calculated as:

$$
Q_{e}=\dot{m}_{e} h_{f g}
$$

where $\dot{m}_{e}$ is the evaporation mass flow rate of the water, and $h_{f g}$ is the latent heat of vaporization. The total daily solar insolation is calculated as:

$$
I_{t}=\int_{t=t_{i}}^{t=t_{f}} I(t) d t
$$

The ratio of the daily solar insolation to the yield rate is an indicative measure of the effectiveness of the system. The lower is this ratio, the higher is the thermal efficiency of the system. This is reflected by the test data presented in Figure 8. The figure shows as the daily solar insolation per yield rate drops below $13 \mathrm{MJ} / \mathrm{L}$, the thermal efficiency of the system increases sharply. The results show the passive distillation system whose basin was un-insulated performed poorly with efficiencies below $9 \%$, while the active distillation system had efficiencies reaching close to $19 \%$. The passive distillation system whose basin was insulated had efficiencies that lied between those two systems. Figure 9 shows the distilled water yield rate as function of the total daily solar insolation. The results show the yield rate peaked at $3.6 \mathrm{~L} / \mathrm{m}^{2} /$ day when the total daily solar insolation reached $33 \mathrm{MJ} / \mathrm{m}^{2} /$ day. 


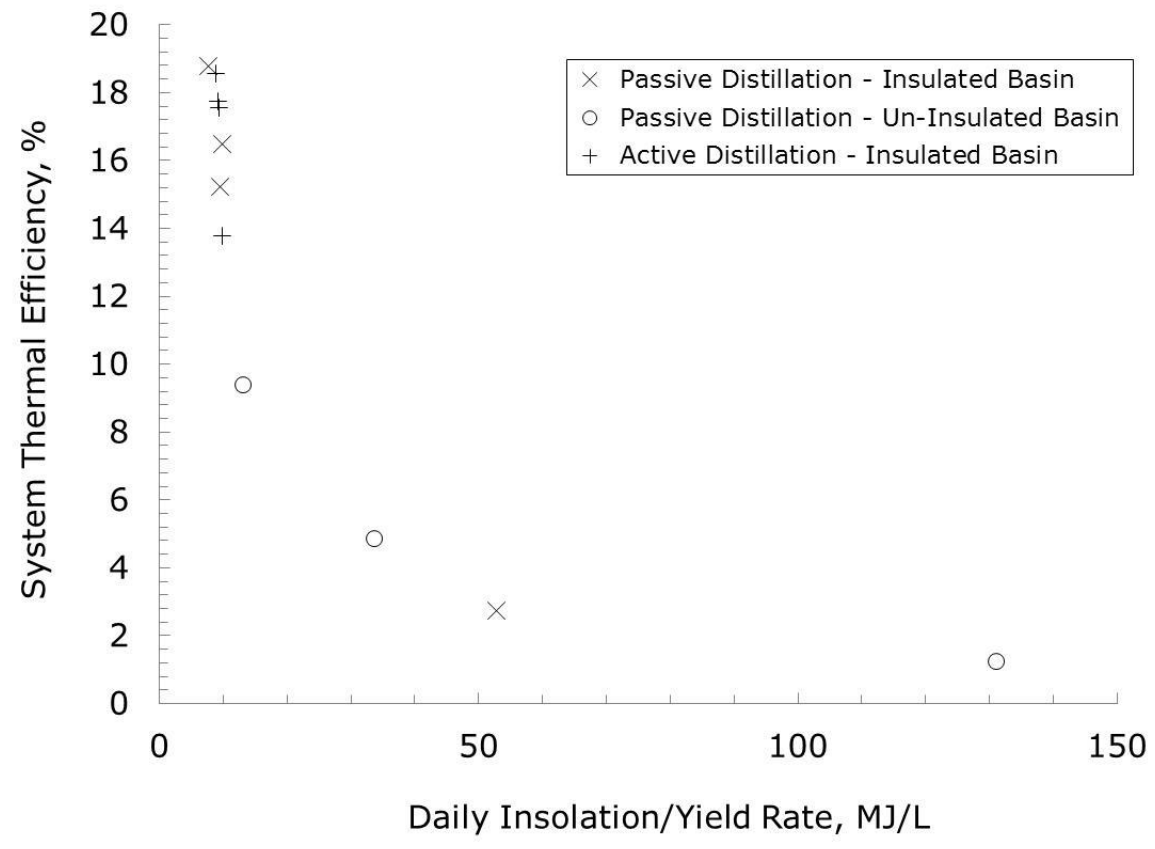

Figure 8. System thermal efficiency versus daily insolation per yield rate

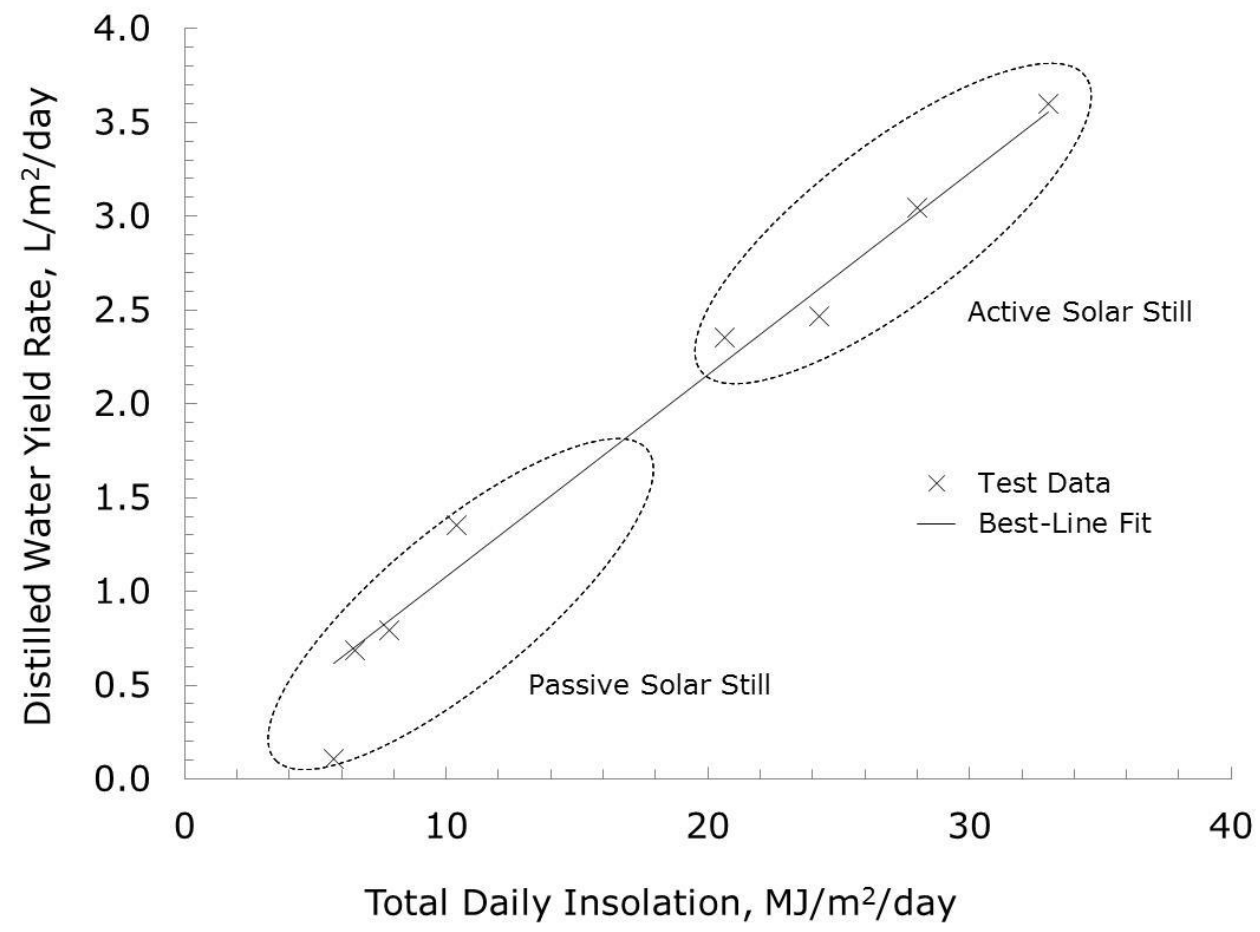

Figure 9. Distilled water yield rate versus total daily insolation 


\section{Conclusions}

An experimental study was conducted on a solar still augmented with a solar collector using evacuated solar tubes. To investigate the feasibility of the solar tubes, stills with and without augmentation were studied. Tests were performed for several days under the climatic conditions of Canyon, Texas. Based on the results of the study, the following conclusions were reached. The maximum daily production was $1.4 \mathrm{~L} / \mathrm{m}^{2} /$ day for the passive distillation system, and $3.6 \mathrm{~L} / \mathrm{m}^{2} /$ day for the active distillation system. The study showed the evacuated solar tubes collector increased the production rate by $263 \%$, and the peak in the thermal efficiency of both systems was about $19 \%$. The yield rate increased almost linearly with the increase in the total daily solar insolation.

\section{Acknowledgement}

The author acknowledges USDA-Ogallala Aquifer Program for financially supporting the project under Grant no. 281119. The author would like to thank the following student research assistants in the Mechanical Engineering Program for assisting in the data collection: Khodor Ibrahim, Duncan Brown, Mitchell Farley, Alex Para, and Miguel Garcia.

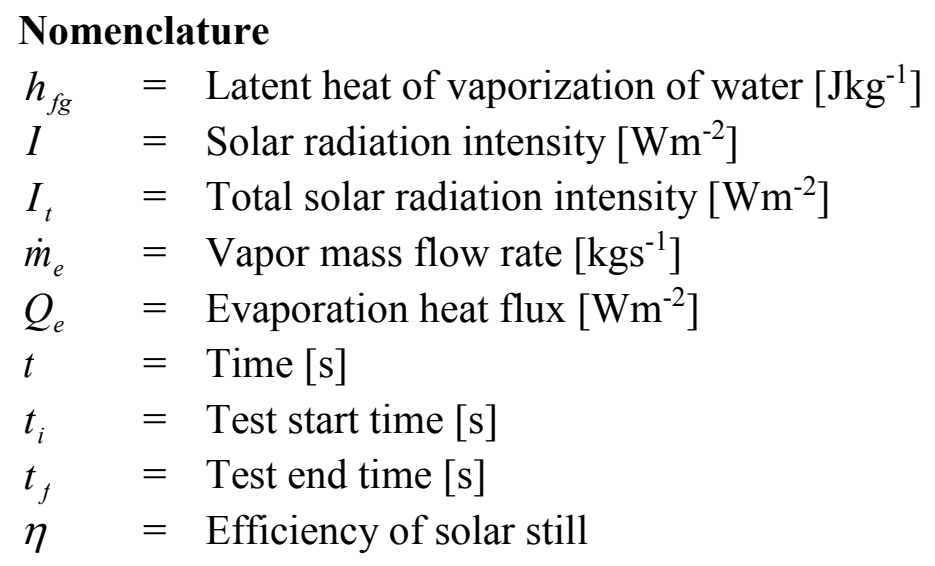




\section{References}

[1] National Weather Service for Amarillo, http://www.nws.noaa.gov/climate . Accessed September 1, 2016.

[2] Soule, J.D., and Piper, D., Farming in Nature's Image: An Ecological Approach to Agriculture, Island Press, Washington, DC, USA, 1992

[3] United States Department of Agriculture-Agricultural Research Service (USDA-ARS), http://www.ogallala.ars.usda.gov

[4] Onyegegbu, S.O., Solar Distillation of Pond (Muddy) Water, Energy Conversion and Management, 24 (1984), 1, pp. 1-4

[5] Onyegegbu, S.O., Nocturnal Distillation in Basin-Type Solar Stills, Applied Energy, 24 (1986), pp. 29-42

[6] Potoglou, D., Kouzeli-Katsiri, A., Haralambopoulos, D., Solar Distillation of Olive Mill Wastewater, Renewable Energy, 29 (2003), pp. 569-579.

[7] Okeke, C.E., Egarievwe, S.U., and Animalu, A.O.E., Effects of Coal and Charcoal on SolarStill Performance, Energy, 15 (1990), 11, pp. 1071-1073

[8] Ayav, P.I., and Atagunduz, G., Theoretical and Experimental Investigations on Solar Distillation of Iztech Campus area seawater, Desalination, 208 (2007), pp. 169-180

[9] ElSherbiny, S.M., and Fath, H.E.S., Solar Distillation Under Climatic Conditions of Egypt, Renewable Energy, 3 (1993), 1, pp. 61-65

[10] Tiwari, A.K., and Tiwari, G.N., Thermal Modeling Based on Solar Fraction and Experimental Study of the Annual and Seasonal Performance of a Single Slope Passive Solar Still: The Effect of Water Depths, Desalination, 207 (2007), pp. 184-204

[11] Abdallah, S., Abu-Khader, M.M., and Badran, O., Effect of Various Absorbing Materials on the Thermal Performance of Solar Stills, Desalination, 242 (2009), pp. 128-137

[12] Badran, A.A., Al-Hallaq, A.A., Salman, I.A.E., and Odat, M.Z., A Solar Still Augmented with a Flat-Plate Collector, Desalination, 172 (2005), pp. 227-234

[13] Badran, O.O, and Al-Tahaineh, H.A., The Effect of Coupling a Flat-Plate Collector on the Solar Still Productivity, Desalination, 183 (2005), pp. 137-142

[14] Sampathkumar, K., and Senthilkumar, P., Utilization of Solar Water Heater in a Single Basin Solar Still - An Experimental Study, Desalination, 297 (2012), pp. 8-19

[15] Singh, R.V., Kumar, S., Hasan, M.M., Khan, M.E., and Tiwari, G.N., Performance of a Solar Still Integrated with Evacuated Tube Collector in Natural Mode, Desalination, 318 (2013), pp. 25-33

[16] Ahmed, M.I., Hrairi, M., and Ismail, A.F. On the characterisitics of multistage solar distillation. Renewable Energy, Vol. 34, Issue 6, June 2009, pp. 1471-1478

[17] Valsaraj, P. An experimental study on solar distillation in a single slope basin still by surface heating the water mass, Renewable Energy, Volume 25, Issue 4, April 2002, pp. 607-612 